\title{
"Whom Science' Hand has Drawn So \\ Near": The Canadian Journal- Scientific Periodical, 1851-61
}

\section{Mark A. Levene}

\begin{abstract}
As the first periodical in Canada West devoted to matters of science and technology, the Canadian Joumal represents an important development in the growth of an intellectual and academic culture in the Colonies. The Journal was established to serve as the record of the proceedings of the Canadian Institute, founded by Royal Charter in 1851 and devoted to encouraging and advancing "the Arts and Manufactures" and to facilitating the acquisition and dissemination of knowledge connected with engineering, architecture, and surveying. The Joumal initially complied with these preliminary guidelines but it gradually evolved in new directions as the focus of both the Institute and its periodical shifted to meet the changing needs of a scien tific community in a structurally shifting society. The changes in the journal over its first years illustrate the way an emergent scientific community interacted with, and indeed contributed to, an economy that was making its first, tentative steps toward capitalism and all that capitalism brought with it.
\end{abstract}

The Canadian Journal was the first periodical in Canada West to devote itself to matters of science and technology and, as such, it represents an important development in the growth of an intellectual and academic culture in the Colonies. The Journal aimed to serve as the "record of the proceedings of the Canadian Institute, and [as] a repertory of Industry, Science and Art."' The Institute, founded by Royal Charter in 1851, devoted itself to encouraging and advancing "the Arts and Manufactures" and to facilicating "the acquirement and dissemination of knowledge connected with the Engineering, Architectural and Surveying Professions." 2 While the Journal initially complied with these guidelines, the focus of both the Institute and its periodical was modified to meet the needs of a scientific community in a rapidly changing society. Not only content but also style and format changed. As the original obtuse quarto format overflowing with print switched to a more 
manageable and concise crown octavo size, ${ }^{3}$ the original emphasis on engineering and surveying-products of the railway age-broadened to include more speculative and pure sciences.

There are two intersecting but distinct currents in the writing of the history of science. One approach privileges the nuts and bolts of scientific discovery, focussing on the act of discovery itself. The present study primarily adopts the orher approach which concentrates less on actual scientific work and more on the implications of scientific activity and its interaction with broader society. It examines the process of scientific development in a small, somewhat isolated and fragmented colony in order to explain how it was economically and socially significant for the larger community. This should enrich our understanding of Upper Canadian society and its preoccupations. The growth of a scientific community around the Institute and its journal was an imporcant step in the colony's efforts to expand economically, integrating itself into an emergent capitalist framework.

Historians have often presented the development of science in Upper Canada teleologically. They have linked the development of both a rigid scientific epistemology and the belief in a cumulative body of pure and applied knowledge with a larger movement seeking to define the idea of progress and its ramifications for nineteenth-century Canada. In her work linking scientific discovery with the process of nation-building, Suzanne Zeller concludes that the popular appeal of science in Victorian Canada induced many Canadians to think that "science and its concomitant, rechnology, made a transcontinental nation seem viable and even inevitable." Similar themes of national development appear in the work of others such as Morris Zaslow, Nancy Christie, and Bill Waiser, who have commented, often unintentionally, on issues of state formation and the growth of bureaucracy, usually through the auspices of the development of the Canadian Geological Survey.' Unintentional, that is, because for the most part the connection between the growth of a scientific community 
and the (slow and uneven) development of the "modern scate" in Upper Canada has been largely unexplored. "Articles by Doug MCCalla and Peter Baskerville in Colonial Leviathan suggest how historians may explore these connections, but the scientific issues still need further study. ${ }^{7}$ While this study cannor fully elaborate this theme, it will offer some suggestions as to how the growth of a scientific community in Upper Canada was crucial to the development to an emergent although still largely undeveloped capitalist economy and, in less obvious ways, to the construction of a modern state in British North America. It will do so by tracking the changes in focus and content of the Canadian Journal between 1851 and 1861 .

The growth of this scientific community in Upper Canada was a product of a fundamental change in the colony's economy. Spurred by dramatic leaps in technological innovations, mostly originating from without, the economy of the colony, along with that of other regions in northeastern North America, became increasingly market-oriented and complex. Douglas McCalla notes in his work on the economic history of Upper Canada that, although the railways were important in the changes, they were not the root cause of the transformation that was integrating Canada West with an emergent international system. ${ }^{8}$ The transformation was neither begun or completed during this period, but it provided a foundation for an idea of progress that would view the colony as a rising commercial-industrial centre. At the centre of this vision resided the railway, symbol of the developing and maturing colony. The boom in railway construction, spurred by the Railway Loan Guarantee Act of 1849 and the Municipal Loan Act of 1852 , energized sociecy. Although not always fully successful these ventures aided in creating both rail lines and a vision of the future. "The Province of Canada," Kenneth Norrie and Doug Owram summarize, "saw great possibilities for commercial, financial, and most ambitious of all, industrial development" and with this development "began to seek ways to break out of the confines of the St. Lawrence valley and to continue the extensive growth that had been so 
central to Canadian economic development." Against this background came the birth of the scientific community in Upper Canada, a community whose concerns and preoccupations resonated in the Canadian Institute and its publication, the Canadian Journal

"The first germ of the Institute," reminisced Sandford Fleming in 1899, "may be traced to a gathering of a few gentlemen in a room near the corner of King and Younge streets, on June 20th, 1849. ${ }^{10}$ There, a group of architects, engineers, and surveyors gathered intending to form an organization that would unite these professions throughout the colony. Little came of that first meeting, but this small group planted the seeds. After attempts to hold another meeting in the early summer and then again in late August fell through, the society began to sprout roots in September of that year. They elected a president, the Hon. H.H. Killaly, but he subsequently changed his mind and declined the office. Other appointees, however, proved initially to be more resilient. Sandford Fleming, J.O. Browne, F.W. Cumberland, and Kivas Tully formed a standing committee to run the ordinary business of the Institute, including writing a constitution. There was considerable discussion over the proposed document. Only Fleming and F.F. Passmore, however, attended yet another meeting in November of that year to discuss a revised constitution. After waiting a considerable time for others to appear, the two proceeded to pass "a series of resolutions with complete unanimity ... time was not spent in long discussions; those present deemed it a dispensable formality to have 'movers' and 'seconders' to the motions submitted."

The decisions reached by this abridged committee circulated. "Happily," Fleming continues, "the young Society galvanized into life." By February of 1850 , the Institute was holding weekly meetings on each Saturday night during the months of November and April. ${ }^{12}$ The first President (or at least the first one who lasted more than two weeks) was 
W.E. Logan, the Director of the Geological Survey of Canada. For the most part, however, Logan was a figurehead whose name provided the necessary status for the Institute to pursue a Royal Charter. The Vice-President, Captain (later Sir) John Henry Lefroy provided the real leadership. ${ }^{13}$ The Sociery offered three classes of memberships: one aimed at those who could present their knowledge and work to other members; a second intended for those who could benefit in their work from reading and hearing from others; and a third class, a carch-all for those interested in the Institute but who did not fit into either of the other classes. The clause defining this last group bears quoting, for it neatly summarizes the goals of the Institute. It included

those who, although they may neither have time nor opportunity of contributing much information, may yet have an ardent desire to countenance a laudable, and to say the least, a patriotic undertaking - a wish to encourage a Sociery, where men of all shades of religion and politics may meet on the same friendly grounds; nothing more being required of the members of the Canadian Institute than the means, the opportunity, or the disposition, to promote those pursuits which are calculated to refine and exalt a people. ${ }^{14}$

With the Institute now firmly established (and members now showing up for meerings), many desired to publish the proceedings of the Society.

The "Prospectus" of the Canadian Journal modestly stated that the periodical was to be of "a useful character." Noting the lack of publications dealing with science and industry, the Journal intended to act as a medium between science and industry: "a knowledge, not only desirable but necessary, to all who entertain any desire to keep pace with that rapid march of intellect, which so strongly and pointedly characterizes the progress of modern civilization." All members of the Canadian Institute would receive a copy (provided they paid the membership fee of $15 \mathrm{~s}$. in advance) and "many able members" volunteered their services to work on the publication. The editorial committee also promised an advertising sheet. ${ }^{15}$ Unfortunately, neither the 
existing copies of the Journal nor the financial records of the Society (as they appeared within the magazine) record the existence of such a sheet.

Advertising was not the only aspect of the journal to remain unfulfilled. Most of the "Prospectus" expressed the intention that the Journalshould serve as a facilizator between science and industry. This did not happen, or at least, not in the intended form. The Canadian Journah particularly its first series, primarily published papers which were presented at the Saturday evening meeting of the Institute. Discoveries that would benefit industry and commerce occasionally appeared at the back of the journal in very small print. And although by the third year of publication (1854) these small notices began to appear more frequently, with the change in format and the beginning of the "New Series" of the Journal in 1856, the links between science and industry became more subtle as the content grew more specialized and theoretical. As the economy of Canada West diversified, a scientific periodical devoted to intellectual enterprise and thought found its own niche. In a society in which the initial emphasis on survival of the colony had evaporated, new concerns developed. ${ }^{16}$ An examination of the shifting content and format of the Canadian Journal reveals elements of this shift.

The first issue of the Canadian Journal appeared in August 1852, complete with an unusually dour motto: "in the infancy of a state, arms do flourish, in the middle-age thereof letters, in the decline and fall commerce."17 The intent of the Journal was to allow letters to flourish. Along with the obligatory homage to the future ("Canada has made a progress so surprising in all that promotes and in all that indicates, the well being of a people: the dream of yesterday has become so-often the reality of to-day. ${ }^{\text {"18 }}$ ), the editors cautioned that the place of the physical sciences in the province was a minor one. Not surprisingly the editors aimed to rectify this deficiency. Among the articles included 
in the first issue was "Indian Remains," written by the Rev. C. Dade, and "On the Atmospheric Phenomenon of Light," by J. Bradford Cherriman of the University of Toronto.

Two themes dominate most of the articles written in the early years of the Journat a Christian idea of progress and the related idea of the steady material improvement of Canada West in particular and the British colonies in general. "The progress which is being made in the construction of the railways ..., "the president of the Canadian Institure in 1854, John Beverley Robinson, pronounced, "must inevitably give to the Province a very different position in the estimation of other countries .... And I believe ... that we may expect to gain no inconsiderable degree of wealth and intelligence ...." The growth of Science was a cumulative process; practitioners built foundations and improved old ideas. The annual address of the president from the previous year makes clear the scientific epistemology: "let us not doubt that [knowledge] will gain ground with rapidity, and receive new impulses, and new rewards, from every endeavor we make." ${ }^{20}$ The pace of scientific growth was not unlike the tremendous growth in the construction of railways. The trains not only provided proof of the material development of the province but also accommodated many opportunities for observation and discovery. The construction of a railway was of "scientific and economic importance," in one case for the study of strata of rock along a railway bed, and in another for the observation of flora and fauna along areas previously inaccessible. ${ }^{21}$

The railways appeared as the embodiment of science; and in turn, they epitomized the improvement of the Canadas. One observer commenting upon the Victoria Bridge of the Grand Trunk Railway insisted that "this remarkable structure will be without rival upon the Continent of America, and may, perhaps, be the most stupendous and imposing work of its class in the world." ${ }^{22}$ Henry Youle Hind, professor at Trinity College, University of Toronto and editor of the first series of the Canadian Journah later wrote in his book, Eighty Years of Progress in British North America, Canadians 
"have constructed a system of railroads far surpassing those of some European powers; ... they have done ... enough to point to a progress which shall place the provinces, within the days of many now living, on a level with Great Britain herself." ${ }^{23}$ Occasionally the Journal printed a dissenting note. One writer, for example, especially concerned with the destruction of public space submitted that

All must admit ... that the interests of the public and of the Railway Companies are one in the most important particulars, and that every facility should be afforded them in endeavoring to establish their works at the most suitable points, but if in so doing it be found expedient that ... public grounds should be peacefully surrendered for the purpose of business-the life and soul of all commercial cities-it ought not to be forgotten that prosperity has some claim on the representations of the public at the present day, and surely some effort should be made, before it is too late to provide breathing space for those who come after us. ${ }^{24}$

But such notes of warning were rare and the editors immediately followed the piece with a glowing prospectus on the Grand Trunk Railway. In the first twelve issues alone, there were twenty-two articles or small notices on the construction and progress of the railway in British North America. The religion of railroads became firmly entrenched in the Canadian Journah subtly altering Thomas Keefer's meditation on the "philosophy of railroads" 25

Trains were not the only preoccupation of scientists in this period. The journal contained articles forming a wideranging and eclectic mix. Four other themes predominated: earth sciences (geology and geography), human sciences (including medicine, anthropology, and sociology), the role of science in society, and finally, industry and commerce. These themes were linked in both the type of questions posed and in the methods employed to answer chese problems. Even beyond the dominance of the "scientific method," the notion of Progress reigned supreme.

On 13 March 1853, an earthquake shook Canada West, and although no one was sure what caused it, there were a 
number of theories. The mostly widely accepted explanation was that barometric pressure and low temperatures may have contributed to the quake. Some dismissed the theory outright, but all agreed to continue monitoring the situation using various charts and diagrams to provide an accurate measure of changing conditions and to correlate these with shifts in the earth's crust. ${ }^{26}$ Meteorological charts had been a feature of the end pages since the first issue, but these now took on an added importance. Exhaustive research compiling and correlating endless amounts of daca marked most of the studies undertaken. In addition to studying atmospherics and geology many articles and essays concerned themselves with the endless classification of animals, flowers, plants, and fossils. These included, among others, studies of birds wintering near Toronto and "Observations on the Leafing and Flowering of Plants." Emplasizing conservation, articles appeared covering disparate methods and tools, such as a new apparatus designed for collecting specimens of natural history, hints for collecting fossils along the Ottawa River, and, not to be forgotten, "Directions for Skinning and Stuffing Birds." 27

While many studies had purely incellectual motives, others, particularly those on geological formations, had as much to do with manufacturing and mining as with academia. "Charcoal as a Deodorizer and Disinfectant" was just one example of many. ${ }^{28}$ Not all finds, however, were as impressive. The third page of the June 1854 issue of the Journal carried an important warning. The editors refuced the notion of the existence of coal in Canada West, noting that the shale found was not prized "black diamond" since "no wilder speculations could be indulged in than artempts at finding coal where black shales appear." 29

Members of the Institute also had an interest in the history of mining. In "The Ancient Miners of Lake Superior," American Charles Whittlesey speculated on the existence of some very old mines in the Lake Superior region having been created by Indians. Intrigued by his discovery, he noted the amount of labour required to keep such an operation viable. "Is the North American Indian," 
he asked, "capable of devising or carrying out any such prolonged and systematic plan of operation?" 30

Discussion of the Native population of Canada in the Canadian Journalextended far beyond the subject of mining; and these interests coincided with a much larger fascination with anthropology. Indians, being close at hand and numerous, were an object of curiosity. Studies turned cowards the question of why many groups were slowly (and some quickly) vanishing. Captain Lefroy raised several hypotheses but concluded that it "may be doubted whether any or all of them are adequate to explain" the disappearance of the Indian. He suspected that "the final solution ... can probably be found only in the supposition of a design of Providence to make way for one race by removing the other." ${ }^{31}$ Of course, probing the existence of Native Canadians and other similar anthropological ventures inevitably provoked troublesome philosophical questions. Scholars who have discussed the tension between science and religion in the province, ${ }^{32}$ have shown that opinions such as the one expressed by Lefroy were not unusual in Canada West. "The question of the unity and common origin of mankind [is] one of the most prominent scientific problems of our day," wrote an unidentified author in 1855. Most perceived science as paralleling religion; together they could help demystify society's vexing questions. One contributor declared "Truth need not fear inquiry." ${ }^{33}$ This open attitude was also evident in the field of medicine. T.K. Chambers wrote that

Man's Creator ordained that he should eat bread in the "sweat of his brow" but he did not ordain that he should eat in the suffering, in the rotting of his vitals, the periling of his soul, and the welcoming of premature death. Though labour is the lot of our species, it is healthy, invigorating labour which is natural to them, and not that which entails mess and pain. ${ }^{34}$

Medicine, or what Chambers called "Industrial Pathology," embraced the scientific quest, gradually deemphasizing the spiritual aspects of healing. 
Outside the Institute, ${ }^{35}$ people in Canada West had little if any contact with most developments in the scientific community, although the question of the origin of man was certainly a contentious and public issue. The members of the Institute went out of their way to stress the importance of science, within the Society as well as through public talks and exhibitions. Most of their discussions, however, occurred at the regular meetings and therefore were of questionable effect. Nevertheless, the records of many of these discussions are useful in revealing member's attitudes towards the course of scientific developments. John Langton, Esquire, MPP, declared that "It would be a waste of time and almost an insult to your understanding to enter into a formal defense of the uses and advantages of scientific knowledge. No such pleading can be required in the middle of the nineteenth century, when the last fifty years [has seen] a crowd of brilliant discoveries. ${ }^{36}$ Members of the institute were similarly optimistic. The Canadian Institute "is rapidly becoming the acknowledged centre of practical and theoretical science ... in Western Canada," the president reported in 1853. At the same meeting the institure elected Francis Hincks, the premier of Canada West, a Life Member, in recognition of his contributions to "a country whose sudden increase in wealth and population, whose outstanding progress in railway enterprise and commercial activity, are unmistakable announcements of her social and political progress, and significant indications of her future destiny." ${ }^{37}$ Hincks and the Canadian Institure were a perfect fit: both held sway under the thrall of railways and progress. His status as a Life Member could not have been more appropriate. "It was in the memorable session of 1849," mused Hincks in his autobiography, "that it became my duty to propose, and carry through the House of Assembly, the first measure for affording Government assistance to railway enterprises.... ${ }^{38}$ The rise of Hincks to provincial premier in 1851 was the watershed event in nineteenthcentury Ontario. Neatly placed at the mid-point, a new order had almost completely shattered the old order of the 
Family Compact. The rise of Hincks represents, in a sense, the furtive wedding of science, commerce, and politics. Robert Baldwin, as Michael Cross has argued, was a man whom the new style had left behind, "his gentry society was doomed once the economic revolution was underway" and he became "the first political victim of the revolution." ${ }^{39}$ Even Upper Canadian loyalty fell in line. A report on a competition for a proposed monument in memory of Sir Isaac Brock concentrated on the glory of the monument rather than that of the man: "there is only one column, either ancient or modern in Europe that exceeds the entire height of the proposed Brock Monument, which is that erected in London by Sir Christopher Wren, in commemoration of the great fire in 1666." 40

The economic shifts to a more commercial and industrial economy did not leave the Canadian Journal untouched. Perhaps its motto was not as out of place as first thought. Arms, the need to survive, had passed but the next stage of letters did not last long, for the triumph of commerce was soon at hand. In the first series of the Journah the growth of industry had, if not a featured, then a noticeable place. Applied science was in vogue: notices on such advances as a "New System of Manufacturing Sugar" and "On the Electroplating of Metallic Articles with White Metals, Aluminum and Silicones, from Clay, Stone and Sand" were common. ${ }^{41}$ One of the main concerns of science and industry was efficient paper-making. With the rapid growth of literacy creating markers for newspapers, magazines, dime novels, and other such products, paper supplies became inadequate, partly because of the lack of an efficient and cost-effective method of production. While experts tried many papermaking theories, one of the more interesting approaches was the use of cow-dung. Overall, though, in keeping with Journal's tone, optimism was the order of the day and the editors felt they had every reason to believe "that the search for paper-making materials is very assiduously pursued in Canada West." ${ }^{42}$ The Journal also devoted much space to industrial and agricultural expositions. The first major account in the journal is that of the London exposition in 
1851, at the Crystal Palace, but reports from other expositions, in the Canadas, Britain, and the United States, soon followed. ${ }^{43}$ By 1854 , reports on industrial advances became more frequent as the union between science and industry grew stronger. The August 1854 issue contained accounts of an electro-magnetic engraving machine, a technique for colouring wool by murexide, and the manufacture of paraffin by bituminous shale. ${ }^{44}$ Another described a device called "The Man Machine," "contrived for the purpose of saving miners time in ascending and descending to and from their work." 45

Information about the evolving membership of the Canadian Institute sheds further light upon the society. The figures in Table 1 represent the paid subscribers to the Journal but the readership was more extensive. There were distribution centres, including many Mechanics' Institutes around the colony (thirty-one in 1855), libraries, such as those of Queen's College and Upper Canada College, plus a number of organizations and libraries in Lower Canada. ${ }^{46}$ The members of the Institute came from all parts of the colony, as well as from outside it. Most (about 190 out of 350 members in 1855), however, were Torontonians. Others represented centres such as Hamilton, Guelph, and Montreal. Members included men whose careers were based on science (such as Henry Youle Hind and Sandford Fleming), but also included prominent lawyers (such as Justice John H. Hagarty, H.C.R. Becher and Skeffington Connor), dergymen (the Rev. T.H.M Bartlett, W. Agar Adamson, and the Rev. H. J. Grasett, for example), medical doctors (including William Hincks, brother of Francis, Professor N. Bethune, and Sir George Duncan Gibb), eminent politicians (including Sir John Beverley Robinson and Francis Hincks), and the lesser known politicians (such as Robert Ferrie and James Ross). ${ }^{47}$ The Institute appears to have been a public meeting place where members of the emerging professional elite in Upper Canada could mingle. 
It is difficult, however, to determine how many subscribers (and who among them) attended regularly. Nevertheless, membership in the organization appears to have been significant, and support for it was strong. By 1855, the Institure laid the groundstone for a new building for the society. ${ }^{48}$

Table 1: Membership in the Canadian Institute by Year $^{49}$

\begin{tabular}{lllllllllllll}
\hline Year & & 1852 & 1853 & 1854 & 1855 & 1856 & 1857 & 1858 & 1859 & 1860 & 1861
\end{tabular} $\begin{array}{lllllllllll}\text { Members } & 181 & \text { n.a. } & 253 & 350 & \text { n.a. } & \text { n.a. } & 614 & 650 & 467^{*} & 462\end{array}$

The middle of the nineteenth-century was a transitional period for the ways in which researchers conducted and presented science. The membership lists for 1855 in which sixteen members are listed as "professor" and others as working for the Geological Society suggests that the practice of science in Upper Canada, as elsewhere, was becoming increasingly professionalized. This period marked the shift from amateur practitioners, termed "gentleman scholars," to more professional, and indeed, academic researchers. The pursuit of scientific knowledge was then, as it is now, an expensive proposition. In the late eighteenth and early nineteenth centuries most of those engaged in science came from wealthy backgrounds. By mid-century, however, science, particularly in England and Scotland, and in Canada through the Geological Institute, was becoming increasingly organized and state-sponsored. In Britain, historian Roy M. MacLoed argues, middle-class practitioners mounted a scientific reform movement, "stimulated by rapid changes in science itself, and witnessing the triumph in reform in social and political affairs generally." 50 As Frank Turner likewise points out in his periodization of science in the nineteenth-century, the period following the Great Exhibition in 1851 witnessed repeated attempts "to forge a genuinely self-conscious professional scientific community based on science pursued according to strictly naturalist [rather than religious] premises." These advocates "repeatedly equated the progress of science with the progress of civilization." 
tensions as well. The alliance of science and education seen in many of the Presidential addresses to the Inscitute parallels the early concerns with railways and the state. Like the railways, scientific education required the sponsorship of the state. If science was equated with progress then it only stood to reason that the greater the amount of scientific interest and activity conducted, the greater the amount of progress achieved. Emphasis on education was a call to the state to involve itself actively in the creation of scientific knowledge. The Crystal Palace Exhibition of 1851 drove home the point that national pride was at stake in scientific endeavours. These subtle and sometimes not-too-subtle pressures strengthened the developing union between science and the scate.

\section{IV}

By 1855 the presidential addresses still addressed the same old issues but their focus had subtly changed over time. George Allen, in his address of 1855, put less emphasis than usual on the broad links between commercial progress and intellectual achievement, emphasizing instead education and the advancement of knowledge. He expected that he would soon find himself living among a people "who ... will be as able as any other that can be named, either ancient or modern, to comprehend the nature and value of discussions that may be made in the arts and sciences." 52 In November of that year, upon the suggestion of anthropologist and literary critic Daniel Wilson, ${ }^{33}$ the Canadian Institute arranged with The Athenæum (a somewhat similar group founded in 1843) to unite the two organizations, giving the Society a membership of over five hundred. ${ }^{54}$ Other changes accompanied the merger. The Institute had desired to change the termination date of each volume (for financial reasons, so the year end of the Journal would coincide with that of the Institute) but the Council had delayed this action until the other changes it had in store for the journal could be put in place 
as it appeared ... that the prospects of the Society were such as would warrant the issue in a short period of a New Series, with such changes in size, form, and arrangement, as would adapt it to the rapid growth and strength of the Canadian Institute. It is now thought that the time has arrived for effecting this change. 55

Under the editorship of Wilson, who replaced Hind, the character of the Journal changed, paralleling a change in direction of the Institute: Chief Justice Draper delivered the president's address inaugurating the New Series, making him the first president without formal ties to the remnants of the Family Compact. ${ }^{56}$

The debut of the New Series in 1856, stressed initiatives to further the expansion of scientific knowledge. The new Journal differed in appearance as well as in content. Formerly the issues had looked more like a newspaper than a magazine. The large pages were full of text; and up to three or four items might appear on one sheet. There was no set arrangement of articles either; Wilson usually spread parts of them throughout a given issue or two. The New Series was more focused; articles were arranged one after the other, and a few issues went so far as to include a cable of contents. Most of the short notes from other countries were gradually replaced by a more excended book review section, 57 or funnelled into a compact section entitled "Scientific and Literary Notes." The result was a more convenient format in which items of interest could be more easily located, and overall, a more sophisticated and, in a sense, professional appearance.

Along with changes in format came changes in content. During Wilson's tenure articles ceased to be exclusively scientific but now included elements of literature and history. When Wilson stepped down as editor in 1860 the Journal became more scientific again but "it never lost the general character that Wilson had given it." 58

The earlier preoccupation in the pages of the Journal with industry and commerce also diminished, perhaps reflecting dampened economic dreams. The hopes that the grand links of canals and railways would rush products of 
the American west to markets in the East and beyond faltered with Peel's abolition of the Corn Laws. Doug Owram, in his study of the Department of Public Works (where science met the State) noted the frustration that followed the realization that the canals would never be able to

pay their real cost, the interest on the capital put into them.... After millions of dollars had been spent and while the Province found itself more than once at the edge of bankruptcy, the lucrative trade of the American Midwest continued to remain as elusive as ever. And during the 1850s, Canadians began to realize just how elusive it was. ${ }^{59}$

This is not to suggest that a fundamencal shift in thinking occurred; but there was a minor retreat from the emphasis on surveying and engineering. The "Preliminary Address" in the first issue of the New Series returned to the usual themes of commercial and industrial prosperity. After the crisis over the British moves to freer trade and the economic downturn of the mid-1850s, however, contributors expressed these sentiments more as hopes than as firm expectations: "it is the desire of every well-wisher of the province, that this advancement in industry and material wealth should not be unaccompanied by some corresponding manifestation of intellectual virility." ${ }^{60}$ The turn away from engineering, surveying, and similar concerns, in the content of the Journal was also, in another sense, an attempt to create a larger space for scientific and intellectual pursuits. As Daniel Wilson expressed it in his president's address in 1860:

Once more we assemble here to renew the work another Session, as a body specially inviting its members to devote their energies to the investigation of the laws of nature, the advancement of science, and the discovery of new truths.

...The functions of this Institute are of a peculiarly important kind, and claim for it a generous encouragement from all who desire the true welfare and advancement of the Province of its future progress I entertain no doubt; for it is impossible that Canada can attain true greatness apart from such elements of mental and moral vigor as it is the special object of the Canadian Institute to develop. ${ }^{61}$ 
In short, the goal of the Canadian Institute was to develop a scientific community and culture. "The time has come," read the report of the editing committee in 1858, "for the maintenance in Canada of a periodical specially devored to original communications in Science and Literature."

The New Series was in no way a repudiation the first five years of the Journal It was an extension, an expanding of the horizon and a redefining of goals. Articles like "Economy of Fuel for Steam Machinery," by Alfred Brunel and "New Compound Railway," by Sandford Fleming, continued to appear. ${ }^{63}$ However, the role of the economy in science became more implicit than explicit; it became an explanation rather than an expectation. James Browne of Toronto, writing about the Aborigines of Australia and surrounding areas, offers a contrast to Caprain Lefroy in his explanation of decline. Browne wrote that most of the native population of Tasmania had disappeared and that those of Australia were not far behind. In their place was "a new and hardy population of industrious settlers derived-it may almost be said without figure of speech-from every nation under heaven; but controlled and guided in the process of civilization by the hardy, practical Anglo-Saxon race." The idea that Anglo-Saxons had a "civilizing" mission, which included the responsibility to impart nineteenthcentury notions of progress and prosperity to others, also applied in Canada. One of the more frequent contributors to the New Series was Francis Assikanack, a full-blood Indian "and a son of one of the Chiefs of the Odawah." In 1840 , Samuel Jarvis, the Superintendent-General of Indian Affairs, sent the sixteen year old Assikanack to Upper Canada College. Overcoming difficulties with the English language, the young man went on to become an accomplished scholar with a working knowledge of Greek and Latin. The commitment to civilizing the Indian was bolstered by the editorial note that accompanied Assikanack's first essay: "So creditable and satisfacrory result of an experiment which at first seemed so hopeless, ought surely to encourage its repetition, and that on a more extended 
scale." The notion was also bolstered by the article itself in which Assikanack explained a legend of the Odawahs as a parable of the tribes of Israel escaping the Egyptians by parting the Red Sea. ${ }^{\circ 5}$

Anthropology was Wilson's specialty and many of his essays on the subject appeared in the periodical. His touch was broad, however, and he wrore voraciously on any number of topics in his idiosyncratic and engaging style. On writing on the ethnographic phases of conchology, for instance, he would weave in a few stanzas of Tennyson's "Maud." His interests ranged from narcotic usage and superstitions of the Old and New Worlds to reviews of Longfellow's "The Song of Hiawatha," Poe's "Tales of Mystery and Poems," and Walt Whitman's "Leaves of Grass." Yet in spite of the literary leanings, one of the main themes expressed by the Journal over this ten year period, in a different form but nevertheless present, emerges. "To call his 'Leaves' poems, would be a mistake;" Wilson comments, "they resemble rather the poet's first jottings, out of which the poem is formed; the ore out of which the metal is to be smelted; and in its present form, with more of the dross than sterling metal in the mass." ${ }^{\text {" }}$ The same could be said of the province's emerging economy making its first hesitant strides towards industrialization. Wilson's metaphor speaks volumes on the times.

Science in the nineteenth century marked the confluence of the conflicting, yet somehow also complementary, strains of thought of utilitarianism and Romanticism. In the private and imaginative sphere of life, Romanticism prevailed. But in public life a utilitarianism took hold that was characterized by an intense desire to subjugate nature and reorganize society in the names of efficiency and higher production. The scientific outlook of the nineteenth century incorporated most of the utilitarian framework but also captured many of the insights of Romantic and expressionist thought. ${ }^{67}$ Indeed, the Canadian Institure was very similar in form and function to the salons in Europe, places where the Romantic spirit flourished. Daniel Wilson embodied both these traditions in one public persona; he would quote poetry 
when discussing the origins of sea shells and would attempt to refute Darwin by appealing to Shakespeare. Self-taught and possessing only an honourary degree, Wilson was the Canadian version of what Walter Houghton has labelled the "half-instructed" person in a time when autodidactism had become popular among the middle classes. This was a period of dogmatism and infallibility fostered by the ignorance of the audiences, most of whom were self-taught themselves. On matters in which so few knew anything about the subjects and topics presented at these public lectures "what an ignorant public encouraged was not checked by the existence of any body of scholars." ${ }^{\text {"68 }}$

Clearly, however, in public life and in science the rriumph of utilitarianism became increasingly evident: in the bureaucratization and rationalization of the economy, in the rise of the State, and in the professionalization of occupations. ${ }^{69}$ These movements generated a new authority. Science and rationality increasingly legitimized actions in the public sphere. Even Daniel Wilson was spellbound by the advance of technology. "Among the triumphs of science in the nineteenth century," he wrote, "we can scarcely contemplate another which shall cast into the shade the successful laying of the great electric cable along the ocean bed of the Atlantic. There appears something of the calm and unostentatious dignity becoming so great an enterprise, in the unheralded announcement of success. ${ }^{70}$ Many years would pass, however, before science would completely supplant religion in public society and, in the memorable phrase of Charles Rosenberg, there would be no other Gods." But in the 1850 s, scientific achievements could still be commemorated with poetry, as a young University of Toronto undergraduate did in his prize-winning "The Atlantic Telegraph": ${ }^{72}$

O you! ye twain of kindred blood,

Whom Science' hand has drawn so near,

That each in each other's ear

Can whisper o'er the mediate flood; - 
By 1860, when Wilson stepped down as editor of the Canadian Journal to become president of the Canadian Institute, a scientific community and culture had begun to develop within Canada West. The seedlings that Fleming, Passmore, and the others had planted slowly began to flower.

\section{NOTES}

- This article is a revised version of a paper initially presented to a graduate seminar at the University of Alberta. I would like to thank David Mills and the rest of the seminar participants for their helpful comments. Thanks also to Jim Bohun, Chris Hackett, and the anonymous referees and the editors of this journal for their comments and encouragement. Research for this paper was aided by a University of Alberta PhD Scholarship and a doctoral fellowship from the Social Sciences and Humanities Research Council of Canada.

"Canadian Institute," Canadian Institute for Historical Microreproductions (CIHM/ICMH) Microfiche Series, 50561 (n.d.), 7. 2"Canadian Institute," СІнм/ІСмH Microfiche Series, 38074 (n.d.), not paginated.

'Or, in other words, from a broad-sheet size to a book size. See The Royal Canadian Institute Centennial Volume, 1849-1949, W. Stewart Wallace, editor (Toronto: Canadian Institute, 1949), 138.

'Suzanne Zeller, Inventing Canada: Early Victorian Science and the Idea of a Transcontinental Nation (Toronto: University of Toronto Press, 1987), 273.

'See Morris Zaslow, Reading the Rocks: The Stony of the Geological Survey of Canada, 1842-1972 (Toronto: Macmillan, 1975); Nancy Christie, "Sir William Logan's Geological Empire and the 'Humbug' of Economic Utility," Canadian Historical Review 75 (1994): 161204; W.A. Waiser, The Field Naturalist: Jobn Macoun, the Geological Survey, and Natural Science (Toronto: University of Toronto Press, 1989).

'On the development of the modern state see Stuart Hall, "The State in Question," in The Idea of the Modem State, Gregor McLennan, David Held, and Stuart Hall, eds. (Milton Keynes: Open University Press, 1984), 1-28.

7See Douglas McCalla, "Railways and the Development of Canada West, 1850-70," in Colonial Leviathan: Stase Formation and MidNineteenth-Century Canada (Toronto: University of Toronto Press, 1992), 192-229; and Peter Baskerville, "Transportation, Social Change and State Formation, Upper Canada, 1841-64," in Ibid., 230-56. 
${ }^{8}$ Douglas McCalla, Planting the Province: The Economic History of Upper Canada, 1784-1870 (Toronto: University of Toronto Press, 1993), 215.

'Kenneth Norrie and Douglas Owram, A History of the Canadian Economy (Toronto: Harcourt Brace Janovich, Canada, 1991), 226-7, 240-1.

"OSandford Fleming, "The Early Days of the Canadian Institute," Transactions of the Canadian Instirute 11-12, parts 1 \& 2: SemiCentennial Memorial Volume. 1849-1899 (Toronto: Canadian Institute, 1899), 2.

"Ibid., 1-2.

'Ibid., 2.

${ }^{13}$ The Royal Canadian Institute Centennial Volume, 1849-1949, 129.

Thomas Ridout, who secured Robert Baldwin's support, also helped with the Charter. Baldwin was married to Ridout's aunt. See, Ibid., 130. On Lefroy, see Carol M. Whitfield and Richard A. Jarrell, "Lefroy, Sir John Henry," Dictionary of Canadian Biography 11 (Toronto: University of Toronto Press, 1982), 508-10.

14"Canadian Institute," сін M/ICMH Microfiche Scries, 5056 I (n.d.), 3. ${ }^{15}$ Ibid., 7-8. The italics are in the original.

${ }^{16}$ For diverse elements of the structural shift in the provincial economy, see, among others, H.C. Pentland, "The Role of Capital in Canadian Economic Development Before 1875," Canadian Joumal of Economics and Political Science 16 (4) (1951): especially 457-463; Peter A. Baskerville, "Entrepreneurship and the Family Compact: YorkToronto, 1822-55," Urban History Review 9 (3) (1981): 15-34; Douglas McCalla, The Upper Canada Trade 1834-1872: A Study of the Buchanans' Business (Toronto: University of Toronto Press, 1979); and Michael S. Cross, "The First Victim: The Canadian Economic Revolution and the Fall of Robert Baldwin, 1851," unpublished manuscript in author's possession.

"Canadian Joumal [hereafter $C J], 1$ (1) (August 1852): 1.

${ }^{18} \mathrm{CJ}, 1$ (1) (August 1852): 1.

${ }^{19} \mathrm{CJ}, 2$ (6) (January 1854): 145. Robinson was contrasting the optimistic situation in Canada with that of the apparent gold bust in Australia where "the circumstance of gold being among the natural productions of a country does not ensure the acquisition of wealth." (145).

${ }^{20} \mathrm{CJ}, 1$ (6) (January 1853): 121.

${ }^{21}$ CJ, 1 (2) (September 1852): 24; "The Northern Railroad-Lake Ontario-Lake Simcoe," CJ, 2 (10) (May 1854): 255.

${ }^{22}$ "The Grand Trunk Railway-The Victoria Bridge," CJ, 2 (11) (June 1854): 200.

${ }^{23}$ Quoted in Laurence S. Fallis, Jr., "The Idea of Progress in the Province of Canada: A Study in the History of Ideas," in The Shield of 
Achilles: Aspects of Canada in the Victorian Age, W.L. Morton, ed. (Toronto: McClelland and Stewart, 1968), 172.

24"Railway Terminal and Pleasure Grounds," CJ, 1 (10) (May 1853): 233.

25"Grand Trunk Railway," CJ, 1 (10): 235: "Index to Volume I," CJ, Vol. 1, iii. T.C. Keefer, civil engineer, wrote "Philosophy of Railroads" in 1849 to support the construction of new lines in Canada. See T.C. Keefer, Philosophy of Railroads and Other Essays, H.V. Nelles, ed. (Toronto: University of Toronto Press, 1972), 3-61.

26" The Earthquake Shock of 13th March, 1853," CJ, 1 (8) (March 1853): 185.

2The five articles described are found in $C J, 1$ (7) (February 1853): 169; $C J 1$ (8) (March 1853): 182, 201; and $C J 1$ (10) (May 1853): 210.

${ }^{28}$ Cl, 3 (4) (September 1853): 337.

29"Coal in Canada," CJ, 2 (11) (June 1854): 202.

${ }^{30} \mathrm{CJ}, 1$ (5) (December 1852): 106-08.

${ }^{31}$ Capt. J.H. Lefroy, "On the Probable Numbers of the Native Indian Population of British America," CJ, 1 (9) (April 1853): 198.

${ }^{32}$ See A.B. McKillop, A Disciplined Intelligence: Critical Inquiny and Canadian Thought in the Victorian Era (Montreal: McGill-Queens University Press, 1979).

3"'The Unity of the Human Race," CJ, 3 (10) (May 1855): 229.

${ }^{3}$ T.K. Chambers, "Industrial Pathology; or the Accidents and Diseases Incident to Industrial Occupations," CJ, 3 (2) (September 1854): 29. "Between 1851 and 1861 attendance at meetings is mentioned only once. On January 1853, attendance "exceeded forty." See CJ, 1 (6) (January 1853): 121. In August 1853, the President's address mentioned almost three hundred members, Cl, 2 (1) (August 1853): 1. By 1855 , paid membership exceeded four hundred, but most probably did not attend meetings regularly.

${ }^{36} J$ ohn Langton "The Importance of Scientific Studies to Practical Men," CJ. 2 (8) (March 1854): 201.

37"President's Address," CJ, 2 (1) (August 1853): 1. For Hincks' election see lbid., 18.

${ }^{30}$ Sir Francis Hincks, Reminiscences of his Public Life (Montreal: William Drysdale and Co., 1884), 201. My italics. See also William G. Ormsby, "Sir Francis Hincks," in The Pre-Confederation Premiers: Ontario Government Leaders, 1841-1867, J.M.S. Careless, ed. (Toronto: University of Toronto Press, 1980), 166-8.

${ }^{39}$ Cross, "The First Victim," 20.

40"Brock Monument," $C$, 1 (2) (Seprember 1852) 41-2.

${ }^{41}$ CJ, 1 (5) (December 1852): 116; and CJ, 3 (1) (August 1854): 15. Indeed, the latter demonstrates one facet of the connection between science, industry, and the arts: "My attention," G. Gore writes, "has 
since been directed to produce simple processes, whereby any person not possessing a knowledge of chemistry may readily coat articles with these metals, and cause the discovery to be immediately applied to human benefit in the arts and manufactures."

42"Materials for Paper-Making-Paper from Cow-dung," CJ, 3 (2) (September 1854): 32, 44.

43"The London Exposition," CJ, 1 (2) (September 1852): 46. For a Canadian example, see "Report on the Provincial Agricultural Show," CJ, 1 (3) (October 1852): 51. Among other exhibits were the "Fine Arts and Ladies' Department" and the "Educational Department." ${ }^{4} \mathrm{CJ}, 3$ (1) (August 1854): 16-18.

4" "Lightening of Labour in Mines-The Man Machine," CJ, 3 (11) June 1855): 266.

${ }^{46} \mathrm{CJ}, 3$ (5) (January 1855): 139-40.

${ }^{47}$ Information on many of these members can be found in R.D. Gidney and W.P.J. Millan's Professional Gentlemen: The Professions in Nineteenth-Century Ontario (Toronto: University of Toronto Press, 1994).

${ }^{4}$ Fred Cumberland, "Announcement of New Building," CIHM/ ICMH Microfiche Series, 43226 (6 November, 1855), not paginated. Cumberland's poster encouraged members to subscribe to the building fund to help "complete a Building worthy of the Canadian Institute of Upper Canada."

${ }^{49}$ Membership figures are based on those published in the journal. Those marked "n.a." indicate years in which no figures were published. The asterisk on 1860 reflects the decision to drop 129 members because of long-term non-payment of dues. See CJ 1 (3) (October 1852): 49-50; $C J 2$ (5) (January 1854): 146-8; CJ 3 (5) Uanuary 1855): 137-40; CJ New Series, 3 (14) (March 1858): 169; CJ New Series, 4: 218; CJ New Series,(March 1861): 193.

${ }^{30}$ Roy M. MacLoed, "The Support of Victorian Science: The Endowment of Research Movement in Great Britain, 1868-1900," Minerva 9 (April 1979): 198.

"Frank M. Turner, "Public Science in Britain, 1880-1900," Isis 71 (259)(1980): 591.

${ }^{52}$ George Allen, "President's Address," CJ, 3 (7) (February 1855): 162. "For Daniel Wilson see Carl Berger, "Wilson, Sir Daniel," Dictionary of Canadian Biography 13 (Toronto: University of Toronto Press, 1990), 1109-14; and A.B. McKillop, "Evolution, Ethnology, and Poetic Fancy," Contours of Canadian Thoughr (Toronto: University of Toronto Press, 1987), 43-58.

34 The Royal Canadian Institute Centennial Volume, 1849-1949, 140. The Athenæum was the creation of the Literary and Historical Society of Toronto and began about 1843. See "Prospectus on an Institution to be called the Athenxum," СІнм/1Смн Microfiche Series, 43738, (c. 1843). See also The Athenaum Club: Club and Social Life in London, 
1824-1974 (London: Heinemann, 1975). There was also an Athenæum in Fredericton, see John M. Brooke. "Annual Address before the Fredericton Athenæum, 17 February, 1851," CIHM/ICMH Microfiche Series, 48640 . The club had been in existence since at least 1847.

ss"The Canadian Joumat-New Series," CJ, 3 (11) (June 1855): 11. ${ }^{56}$ On Draper's Presidency, the Centennial Volume notes that "during these years change was busy in the Institute. ...[T] he series of presidents who represented what may be described as the 'Family Compact' element in Toronto society, came to an end, and they were succeeded by a long line of more humble men." (142).

"The Canadian Joumal received quite a number of books from "publishers and others" and "it is proposed to record in each number. a list of Books and Periodicals received; reserving to the Editing Committee the further selection of those for special notice, which shall appear to them the best suited ... for members of the Canadian Institute." See CJ New Series, 5: Postscript, 570.

sa The Royal Canadian Institute Centennial Volume, 1849-1949, 142 3.

"Douglas Owram, Building for Canadians: $A$ History of the Department of Public Works (1840-1960) (Ottawa: Public Relations and Information Services, Public Works of Canada, 1979), 66.

cou"Preliminary Address," CJNew Series, 1 (1): 1.

"Daniel Wilson, "President's Address," CJNew Series, 5 (26): 1.

${ }^{62} \mathrm{CJ}$ New Series, 3 (14) (March 1858): 180.

${ }^{63}$ CJ New Series, 1 (4) (July 1856): 336; CJ New Series, 3 (18) (November 1858): 473.

"James Browne, "Superstitions and Traditions of the Aborigines of Australia," CJNew Series, 5 (6) (November 1856): 511.

${ }^{65} \mathrm{~F}$. Assikanack, "Legends and Traditions of the Odawah Indians," $C J$ New Series, 3(14): 111.

${ }^{66 " S o m e ~ E t h n o g r a p h i c ~ P h a s e s ~ o f ~ C o n c h o l o g y, " ~ C J N e w ~ S e r i e s, ~} 1$ (17) (September 1856): 2; "Narcotic Usages and Superstitions of the Old and New Worlds," CJNew Series, 2 (11) (September 1857): 324; and for the reviews, see, in order, CJNew Series, 1 (1) (January 1856): 48; Ibid., 2 (8) (March 1857): 103; and Ibid., 1 (6) (November 1856): 541.

${ }^{67}$ Charles Taylor neatly and clearly charts the development of the broad currents of thoughts arising out of Hegel's work and contextualizes them in the framework of the emergence of modern society. See Charles Taylor, Hegel (New York: Cambridge University Press, 1973), 540-3.

${ }^{60}$ Walter E. Houghton, The Victorian Frame of Mind (New Haven: Yale University Press, 1957), 139-42. 
${ }^{69}$ See Harold Perkin. The Rise of Professional Society: England Since 1880 (London: Routledge, 1989), 1-26. Perkin defines professional society as "one structured around career hicrarchies rather than classes, one in which people find their place according to trained expertise and the service they provide rather than the possession or lack of inherited wealth or acquired capital." (359).

rDaniel Wilson. "The Aclantic Telegraph," CJ New Series, 1 (17) (September 1856).

"Charles Rosenberg. No Other Gods: On Science and American Social Thought (Baltimore: The Johns Hopkins University Press, 1976). "nJ.A. Boyd, "The Atlantic Telegraph," CJ New Series, 4 (22) (August 1859): 337. 